\title{
T-cell immunodeficiency with epidermodysplasia verruciformis
}

INSERM

\section{Source}

INSERM. (1999). Orphanet: an online rare disease and orphan drug data base. T-cell immunodeficiency with epidermodysplasia verruciformis. ORPHA:324294

T-cell immunodeficiency with epidermodysplasia verruciformis is a rare primary immunodeficiency characterized by increased susceptibility to infection by human papillomavirus, presenting in childhood with disseminated flat wart-like cutaneous lesions. Burkitt lymphoma has also been reported. Whilst total T-cell counts are normal, there is impaired TCR signaling, profound peripheral naive T-cell lymphopenia with memory Tcells displaying an exhaustion phenotype. 